\title{
Papado e episcopado no Vaticano II
}

\author{
The papacy and episcopate in Vatican II
}

D. Filippo Santoro

\section{Resumo}

O artigo estuda o ministério do papa em relação com o episcopado, nos laços do affectus collegialis. Comenta-se a hermenêutica do Vaticano I e a eclesiologia do Vaticano II. Esta é permeada de uma dimensão sacramental, onde o ministério petrino é compreendido no sacramento da ordem episcopal, a um título particular, no âmbito da sollicitudo omnium ecclesiarum e da conspiratio in unum. A perspectiva parte do colégio apostólico, instituído por Cristo e perpetuado nos sucessores, unidos no fundamento da Igreja universal. Considera-se a especificidade do ministério petrino junto com a koinonia das Igrejas, relacionando Igreja universal e Igreja particular, e o bispo de Roma com o colégio Episcopal. Tem-se em vista a unidade do episcopado e o caráter epicopal do primado. Existe um fundamento eucarístico na Igreja, visto que a eucarista é celebrada em determinada comunidade e torna presente a Igreja inteira. O ministério de comunhão é sustentado pelo Espírito Santo, sendo competência de todos os bispos a sollicitudo omnium ecclesiarum, e de Pedro a tarefa de promover a comunhão visível dos crentes, no seio e ao serviço da missão episcopal, como centrum unitatis. O primado inclui o poder de reger na fé e na disciplina. O primado se relaciona com o dinamismo sinodal, que implica envolvimento de todos na fé e prodigaliza ajuda para as decisões. $\mathrm{O}$ artigo conclui com uma referência à teologia ortodoxa. 
Palavras-chave: Ministério petrino; episcopado; colegialidade; sinodalidade.

\begin{abstract}
The article studies the ministry of the papacy in relation to the ministry of the episcopate, within the links of affectus collegialis. It comments on the hermaneutic of Vatican I and the ecclesiology of Vatican II. This ecclesiology is permeated with a sacramental dimension, where the Petrine ministry is understood within the sacrament of the episcopal order, as a particular title, within the sphere of sollicitudo omnium ecclesiarum and of conspiratio in unum. The perspective begins from the apostolic college instituted by Christ and continued in their successors, united in the framework of the universal Church. It considers the specificity of the Petrine ministry, along with the koinonia of the Churches, linking the universal Church and the particular Church, and the Bishop of Rome with the episcopal college. It considers the unity of the episcopate and the episcopal character of the primacy. There is a Eucharistic foundation for this in the Church, since the Eucharist is celebrated in a particular community and makes present the entire Church. The ministry of communion sustained by the Holy Spirit, and the sollicitudo omnium ecclesiarum is the province of all the bishops, and it is the task of Peter to promote the visible communion of believers within and at the service of the episcopal mission, as centrum unitatis. The primacy includes the power to lead in the areas of faith and of discipline. The primacy is related to the synodal dynamism, which implies the involvement of all in the faith and lavishes help for decisions. The article concludes with a reference to Orthodox theology.
\end{abstract}

Keywords: Petrine ministry, episcopate, collegiality, synodality.

\title{
Introdução
}

A relação entre papado e episcopado é um tema bastante delicado e fascinante, objeto de tantos estudos e aprofundamentos, de ásperas discussões em diferentes sedes institucionais, acadêmicas, ecumênicas. No cenário eclesial que estamos vivendo com o papa Francisco, este tema está se configurando em uma perspectiva, com traços também originais, onde de repente está imersa a relação profunda papa-sede romana, e o grande valor, atribuído à dimensão colegial da Igreja, às conferências episcopais, às quais se quer dar mais espaço, maior auto- 
nomia na ação não só em matéria pastoral, mas também de fé, como evidenciou na sua exortação Evangelii Gaudium 32, primeiro texto magisterial totalmente seu. O percurso aqui proposto visa a interpretar o dado magisterial do Vaticano II sobre o ministério do papa na sua relação com o episcopado. Não é uma reflexão específica só sobre o ministério petrino, mas uma tentativa de colher os laços profundos e as estruturas que realizam o affectus collegialis.

\section{Algumas premissas teológicas e históricas fundamentais}

Podemos desenvolver a reflexão sobre o relacionamento entre papado e episcopado, considerando, antes de tudo, qual é atualmente a doutrina católica sobre este ponto. Escreve a tal propósito Ratzinger que "é doutrina indiscutível da Igreja, antes de tudo, que ao papa compete o poder de jurisdição imediata e ordinária, no sentido de verdadeiro poder episcopal sobre toda a Igreja". ${ }^{1}$ A grande novidade do Vaticano I consiste na colocação do bispo de Roma, não acima ou de fora do conjunto dos bispos, mas no interior do corpo episcopal, na esteira de uma leitura do ministério papal, oferecida por Dom Zinelli, secretário da deputação da fé no Vaticano I. É preciso recordar que o Vaticano I não pôde levar ao término o projeto De Ecclesia por causa da conclusão repentina do concílio pela guerra franco-prussiana. Por consequência, tendo entregado só o texto de Pastor Aeternus não houve a possibilidade de ter outro aspecto, aquele do episcopado, que deveria ter sido objeto do debate conciliar e de posterior documento específico. Além disso, certa visão ultramontana emergiu de repente já antes do concílio com visões redutoras e exageradas que levaram quase a "sacralizar" a figura do pontífice, indo além da intentio princeps do concílio mesmo. Serve de prova toda a teologia da escola romana que se desenvolveu em torno de uma compreensão do primado papal que dá a ideia mais de um "mono-episcopado" católico que de uma visão "colegial" na qual o papa é "o initium episcopatus".

Um papel determinante na hermenêutica do Vaticano I foi representado pela intervenção dos bispos alemães pelas provocações de von Bismarck. ${ }^{2}$

1 RATZINGER, J. Primato, Episcopato e "successio apostolica". In RAHNER, K. RATZINGER, J. Episcopato e primato. Brescia: Morcelliana, 2007, 47.

${ }^{2}$ Este despacho (de Bismack datad de 14 de maio de 1872) pretende que as decisões do Concílio do Vaticano comportem as seguintes consequências:

1. O Papa pode atribuir em toda a diocese os direitos episcopais e substituí-los com o próprio poder episcopal.

2. A jurisdição episcopal é absorvida pela jurisdição papal. 
Consequência disto é que "diante dos governos civis eles se tornaram oficiais de um soberano estrangeiro" que pela sua infalibilidade "goza de uma autoridade totalmente absoluta, mais que qualquer outro monarca no mundo". ${ }^{3}$ Em virtude de tais afirmações o episcopado alemão reage com força e desmonta o que foi afirmado, oferecendo uma correta leitura das decisões conciliares.

Segundo estas decisões, a autoridade de jurisdição eclesiástica, possuída pelo papa, é uma 'potestas suprema, ordinaria e immediata', conferida ao papa pelo Senhor nosso Jesus, na pessoa de São Pedro e estende-se diretamente sobre toda a Igreja e, por isso, sobre todas e cada uma das dioceses e sobre todos os fieis para a manutenção da unidade da fé, da disciplina e do governo da Igreja; e não é simplesmente uma autoridade consistente com alguns direitos reservados. Esta não é uma doutrina nova, mas uma verdade da fé católica reconhecida desde sempre..., que o concilio Vaticano... novamente declarou e confirmou, em oposição aos erros dos galicanos, dos jansenistas e dos febronianos. Segundo esta doutrina da Igreja católica, o papa é bispo de Roma, não bispo de alguma outra diocese ou cidade... Mas enquanto bispo de Roma ele é também papa, isto é, pastor e chefe da Igreja universal, chefe de todos os bispos e de todos os fieis; e a sua autoridade papal não tem vigor apenas em alguns determinados casos excepcionais, mas subsiste e obriga sempre, em todo tempo e em todo lugar. Em virtude de tal ofício seu, o papa tem o dever de velar a fim de que todo bispo em toda a extensão do seu cargo cumpra os seus deveres; e onde um bispo fosse impedido ou a necessidade o requeresse, o papa tem o direito e o dever, não como bispo desta ou daquela outra diocese, mas como papa, de ordenar tudo o que diz respeito à administração da mesma. ${ }^{4}$

3. O Papa não exerce mais, como no passado, certos direitos reservados, determinados, mas é depositário do poder pleno e inteiro.

4. Em princípio, o Papa substitui individualmente qualquer bispo.

5. Depende só do Papa intrometer-se a qualquer momento na prática no lugar do bispo em relação aos governos.

6. Os bispos não são apenas instrumentos do Papa, seus funcionários sem responsabilidade própria.

Os bispos tornaram-se, perante os governos, funcionários de um soberano estrangeiro, e, em verdade, de um soberano; graças a sua infalibilidade, é um perfeito soberano absoluto, acima de qualquer outro monarca do mundo. DENZINGER-HÜNERMANN (DH) 3112.

${ }^{3} \mathrm{DH} 3112$.

${ }^{4}$ DH 3113. 
Tillard, teólogo conhecido, consultor do Vaticano II e insigne ecumenista, acentua que além da distinção entre poder eclesiástico e estatal, se confronta também a afirmação da instituição divina seja do papado seja do episcopado, que não se excluem mutuamente, mas se exigem reciprocamente, sem que um englobe o outro. ${ }^{5} \mathrm{O}$ texto da Mirabilis illa constantia de 4 de março de 1875, com a qual Pio IX confirmava a tese do episcopado alemão, tem uma validade eclesiológica particular. ${ }^{6}$ A declaração retoma - segundo o papa "a doutrina católica autêntica" e, portanto, exprime bem o que pretendiam propor o concílio e a santa Sé.

\section{O ministério petrino como ministério verdadeiramente episcopal}

Tudo que foi afirmado pelos bispos alemães foi plenamente recebido pelo Vaticano II, antes podemos dizer que toda a eclesiologia conciliar está permeada de uma dimensão sacramental. Disto deriva, pois, que o ministério petrino pode ser compreendido adequadamente só no interior do sacramento da ordem episcopal, isto é, só no âmbito da sollicitudo omnium ecclesiarum própria de todo bispo e da conspiratio in unum que insere toda a Igreja local na unidade da Catholica. ${ }^{8}$

Para o bispo de Roma como para o conjunto dos bispos, tudo deriva de um mesmo e único sacramento (o episcopado), da uma mesma e única missão que é aquela de construir e conservar a Igreja na comunhão, de um mesmo e único poder dado em consideração desta missão. Mas este poder é diversamente atualizado segundo o ofício que se recebe no colégio: no bispo de Roma a dimensão da 'sollecitudo universalis' se desenvolve a um título particular, porém sempre no interior da graça sacramental do episcopado. ${ }^{9}$

A reflexão sobre o ministério petrino, a partir da consideração da sua natureza episcopal, nos permite evidenciar a peculiar colocação da eclesiologia conciliar: se no Vaticano I emergia uma visão da Igreja que partia do

${ }^{5}$ Cf. TILlARD, J. M. R.. Chiesa di Chiese. L'ecclesiologia di communione. BTC 59, Brescia: Queriniana, 1989, p. 312-315.

${ }^{6}$ PIO IX. Lettera apostolica Mirabilis illa constantia, 4 de marzo 1875: DH 3117.

${ }^{7}$ DH 3120 .

${ }^{8}$ Cf. NIGRO, F. Il vescovo di Roma, "Initium episcopatus" nell'ecclesiologia di communione di J.M.R. Tillard o.p., Assis: Cittadella Editrice, 2011, p. 202.

${ }_{9}^{9}$ TILLARD, J.M.R. Il vescovo di Roma. Brescia: BTC 47, 1985, p. 49-50. 
"chefe", o bispo de Roma. No Vaticano II se parte, ao invés, do colégio apostólico instituído por Cristo mesmo e perpetuado em seus sucessores, os quais estão todos unidos no fundamento da Igreja universal.

O implante colegial está presente claramente em LG 18, onde se recupera e retoma o ensinamento do Vaticano I sobre o primado e sobre o magistério infalível do romano pontífice, mas se introduzem também alguns elementos de novidade:

Este sagrado Sínodo, seguindo os passos do Concílio Vaticano I, com ele ensina e declara que Jesus Cristo, pastor eterno, edificou a Igreja tendo enviado os Apóstolos, como Ele fora enviado pelo Pai (cfr. Jo 20, 21); e quis que os sucessores deles, os Bispos, fossem pastores na Sua Igreja até ao fim dos tempos. Mas, para que o mesmo episcopado fosse uno e indiviso, colocou o bem-aventurado Pedro à frente dos outros Apóstolos e nele instituiu o principio e fundamento perpétuo e visível da unidade de fé e comunhão. Este sagrado Concílio propõe de novo, para ser firmemente acreditada por todos os fieis, esta doutrina sobre a instituição perpétua, alcance e natureza do sagrado primado do Pontífice romano e do seu magistério infalível, e, prosseguindo a matéria começada, pretende declarar e manifestar a todos a doutrina sobre os bispos, sucessores dos Apóstolos, que, com o sucessor de Pedro, vigário de Cristo e cabeça visível de toda a Igreja, governam a casa de Deus vivo. ${ }^{10}$

Notamos logo o apelo ao Prólogo de Pastor Aeternus e a explicitação da missão própria do papa: ser princípio e fundamento, isto é, o início fundante da natureza comunal da Igreja na sua experiência de fé. Não é o único bispo em sentido absoluto, nem o único garante da fé, mas o initium episcopatus, retomando assim uma feliz expressão cipriana ${ }^{11}$ que bem exprime esta relação um-muitos, papa-bispos e todos regem a Igreja. Logo, à lógica da subordinação segue a eclesiologia de comunhão, graças também à contribuição oferecida pela teologia oriental e à recuperação da teologia dos Padres. Em Pedro, de fato, todo apóstolo se reconhece; todo bispo encontra no vigário de Pedro aquela autenticidade do ministério episcopal do qual ele é garantia e sustento.

\footnotetext{
${ }^{10}$ Lumen Gentium (LG) 18: Enchiridion Vaticanum (EV) 1/329.

${ }^{11}$ Cf. TILLARD, J.M.R. Il vescovo di Roma, p. 130-134; J.M.R. TILLARD. Chiesa di Chiese, p. 306-309. CIPRIANO DI CARTAGINE, Lettera 59,14: CCSL III C, 361-362: “à sede de Pedro e à Igreja principal, da qual teve origem a unidade dos sacerdotes (initium/unitas sacerdotii)"; o texto original diz: "unitas sacerdotalis".
} 
Mesmo conceito aparece também na tradição de Ireneu de Lião, como o próprio Tillard sublinha:

É notório como Ireneu não considera Pedro um bispo: é sobre a 'cathedra' da Igreja que se retoma a ele e a Paulo, que se sucederam os bispos. Neste sentido fundador e transcendente, ele é por esta sede 'initium episcopatus', e terá nos vigários desta sede dos vigários, segundo a expressão de Cipriano que atravessará os séculos. O bispo de Roma é, pois, "vigário de Pedro" sobre a 'cathedra' da Igreja que, no dizer de Ireneu, possui a 'potentior principalitas' que vem da sua origem. ${ }^{12}$

Se for mesmo verdadeiro que sua função de initium episcopatus é propriamente em relação à sede romana, não se pode desconhecer que analogamente este conceito é aplicável à relação Pedro-apóstolos, logo, bispo de Roma-bispos. A proeminência de Pedro no colégio apostólico está ligada a uma escolha divina que o fez testemunha da verdadeira fé (cfr. Mt 16, 18) e o defensor fidei que confirma a fé dos fieis (cfr. Lc 22, 31-32). "Sua fé desenvolve parte decisiva para a formação da comunidade primitiva. O "primado" de Pedro é entrelaçado na sua confissão da fé e no seu serviço desta". ${ }^{13}$

Onde e como o Vaticano II fala do papa e da sua relação com o episcopado? No esquema já apresentado do III capítulo da Lumen Gentium emergem alguns aspectos interessantes. No proêmio, ou seja, LG 18, emerge o status quo da doutrina católica, se busca retornar às fontes do episcopado e do primado segundo um procedimento histórico-genético onde emerge em LG 19 a relação Pedro, chefe do colégio apostólico, escolhido entre os apóstolos; portanto, uma unidade de fundo e uma natureza comum (apostólica primeiramente, episcopal depois). Na LG 20 emerge a visão da Igreja como "sociedade hierarquicamente organizada" onde os bispos são já pelo seu nome os "vigilantes" da grei, e com uma linguagem que por certos aspectos retoma ainda a teologia clássica se sublinha a instituição divina dos sucessores dos apóstolos in primis de Pedro/papa. O parágrafo 21, tratando da sacramentalidade do episcopado, coloca no coração do tratamento a relação papa-bispos. A causa ontológica do episcopado é a ordenação, mas a condição que determina

12 TILlARD, J.M.R.. Chiesa di Chiese, p. 308. IRENEO DI LIONE, Adversus Haereses, III, 3,1-3: PG 7, 848-849; BATTIFOLI, P. Cathedra Petri, études d'histoire ancienne de l'Église, Unam Sanctam 4, Paris, 1938, p. 95-103.

${ }^{13}$ TILLARD, J.M.R. Il vescovo di Roma, 127. Cf. O'COLLINS, G. Peter as Easter Witness, in "The Heytrop Journal" 22 (1981) p. 1-18. 
a possibilidade mesma do exercício dos três ofícios é a "comunhão hierárquica com a cabeça e com os membros do colégio episcopal", ${ }^{14}$ esta realidade comunal se expressará com a missão canônica, a eleição e a comunhão com o papa e os outros bispos: como foi devidamente evidenciado na Nota explicativa prévia. Portanto, o papa e os bispos têm em comum a sagrada ordem, torna-se papa por eleição não por ordenação, pela designação para a sede de Roma, memória de Pedro e Paulo, não por um ato consacratório específico. Este dado é fundamental para reconhecer, como dizia já o Vaticano I, que o "vere episcopalis" do múnus petrino do papa é a chave de leitura própria da sua missão/serviço na Igreja.

O texto fundamental do concílio sobre o relacionamento papa-bispos é representado por LG 22. Logo, colhemos o teor linguístico: 5 vezes se fala da relação "cum Petro" e uma só vez "sub Petro", uma inversão de marcha a respeito da teologia precedente, mas também clara mensagem para dar um novo valor ao episcopado no seu conjunto. Compare um paralelismo entre Pedro e os apóstolos, como também entre papa e bispos, e se estreitam os laços de comunhão, que desde antiquíssima tradição uniam os bispos com a sede romana. "O colégio ou corpo episcopal não tem autoridade a não ser em união com o Romano Pontífice, sucessor de Pedro, entendido com sua cabeça, permanecendo inteiro o poder do seu primado sobre todos, quer pastores, quer fieis". ${ }^{15}$ Logo emerge o fato que o episcopado como colégio não pode existir sem seu chefe, por isso, podemos entender o corpo eclesial como uma hélice com dois focos: um ocupado pelo papa e outro pelo episcopado no seu conjunto com o papa como chefe. Por isto, a autoridade do papa está sempre em referência ao episcopado e nunca desligada ou em oposição ao episcopado, mas sua potestas, isto é, a possibilidade de agir e de intervir está desvinculada de um placet dos bispos e está direta e imediata sobre todos os bispos e fieis, em virtude daquela primazia que lhe foi concedida em e com Pedro. Não se trata de "ditadura", como alguém poderia entender maliciosamente, mas de poder real que tem como único fim a edificação mesma da Igreja e a comunhão de fé e de caridade de toda a Igreja e, portanto, também do episcopado.

O texto continua afirmando que:

A Ordem dos Bispos, que sucede ao colégio dos Apóstolos no magistério e no governo pastoral, e, mais ainda, na qual o corpo apostólico se continua perpetuamente, é também juntamente com o Romano Pontífice, sua

${ }^{14}$ LG 21: EV 1/335.

${ }^{15}$ LG 22: EV 1/337. 
cabeça, e nunca sem a cabeça, sujeito do supremo e pleno poder sobre toda a Igreja, poder este que não se pode exercer senão com o consentimento do Romano Pontífice. Só a Simão colocou o Senhor como pedra e clavário da Igreja (cfr. Mt 16, 18-19), e o constituiu pastor de todo o Seu rebanho (cfr. Jo 21, 15ss); mas é sabido que o encargo de ligar e desligar conferido a Pedro $($ Mt 16,19) foi também atribuído ao colégio dos Apóstolos unido à sua cabeça (Mt 18,18; 28, 16-20)". ${ }^{16}$

Ao evidenciar o proprium dos bispos enquanto responsáveis pelo bem das suas Igrejas e pelo bem de toda Igreja, sublinha o fiel respeito em relação ao chefe e como Espírito consolida a estrutura colegial de modo "orgânico" e na "concórdia". A organicidade, que diz unidade e universalidade, sinergia na pluralidade e a concórdia retomam o aspecto da comunhão "efetiva" e "afetiva" que deve animar o colégio no seu conjunto.

Este parágrafo 22 se conclui, enucleando as "modalidades" concretas desta ação colegial, antes de tudo o concílio "convocado, presidido e confirmado" pelo Papa, ou mesmo outras possibilidades não explicitadas do exercício desta colegialidade quando o episcopado mundial pode ser contatado e envolvido por decisões importantes ou também o Papa pode aprovar ou aceitar livremente o que os bispos decidiram afim de que este ato seja autenticamente expressão de todo colégio. Aqui foram abertas várias possibilidades também de renovação da ação colegial na perspectiva da "communio" e da "recognitio/receptio" da parte do Papa.

\section{Igreja Universal e Igreja Particular}

Autoridade do bispo de Roma com principium unitatis fidei et communionis não duplica ou sufoca a responsabilidade do bispo local mas, ao contrário, garante sua verdadeira dimensão: coloca a koinonia das Igrejas, lá onde a edificação da Igreja local encontra a sua plena medida. Portanto a especificidade do ministério petrino pode ser ulteriormente explicitada compreendendo a relação entre primado e episcopado como caso particular do relacionamento entre Igreja universal e Igreja particular. In LG 23 reencontramos as mútuas relações que intercorrem entre: Papa nos limites da Igreja universal, os bispos em suas Igrejas particulares e o colégio nos limites de toda Igreja. Se, nos primeiros dois casos (Papa e bispo diocesano), são "perpétuo e

${ }^{16}$ LG 22: EV 1/337. 
visível principio e fundamento dos fieis", um para Igreja universal e outro para sua diocese, o concílio recorda que a Igreja universal não é uma agremiação de tipo sociológico de tantas igrejas (portanto segundo uma visão de "baixo") nem exprime uma visão "platônica" da Igreja, a ideia/conceito de Igreja que se realiza nas Igrejas particulares, mas "in quibus et ex quibus uma et unica Ecclesia catholica exsistit". Este texto é um dos mais problemáticos e incompreendidos do concílio. E necessário interpretar corretamente o parágrafo 23 da Lumen gentium da qual se extrai "Locus theologicus" da relação da Igreja local - Igreja Universal. ${ }^{17} \mathrm{O}$ documento da CDF "Communionis Notio" atesta:

Para compreender o verdadeiro sentido da aplicação analógica do termo comunhão junto às Igrejas particulares, é necessário antes de tudo levar em conta que estas, enquanto "partes da única Igreja de Cristo" (CD 6: EV 1/584) têm em tudo, isto é com a Igreja universal, uma peculiar relação de "mutua interioridade", porque em toda a Igreja particular "está verdadeiramente presente e age a Igreja de Cristo, una, santa, católica e apostólica". Por isso, "a Igreja Universal não pode ser concebida como a soma das Igrejas particulares e nem como uma federação de Igrejas particulares". Essa não é resultado de sua comunhão, mas no seu mistério essencial, é uma realidade ontologicamente e temporalmente prévia a qualquer Igreja particular. ${ }^{18}$

A carta Communionis Notio fala de "mútua interioridade" entre a Igreja universal e aquelas particulares, mas também de "prioridade ontológica e temporal"; também seu comentário oferecido pela mesma Congregação depois de um ano da publicação revela pontos interessantes que esclarecem o texto.

\footnotetext{
17 "Os bispos, individualmente, são o principio visível e o fundamento da unidade das suas Igrejas particulares, as quais são formadas à imagem da Igreja universal (ad imaginem Ecclesiae universalis fomatis): nesta e a partir desta existe a una e única Igreja católica (in quibus et ex quibus una et unica Ecclesia catholica exsistit)" EV 1/338. Cf. PIÉ-NINOT, S. Ecclesiologia, 371-383. Idem, Ecclesia in et ex ecclesiis (LG 23). La catolicidad de la "Communio Ecclesiarum" in CHICA, F. - PANIZZOLO, S. - WAGNER, H. (ed.). Ecclesia tertii millennii advenientis. Fs. P. A. Antón, Casale Monferrato (AL), 1997, 276-288. PHILIPS, G. La Chiesa e il suo mistero nel Concilio Vaticano II. Storia, texto e comento della Costituzione Lumen Gentium, vol. II, Milano, 1969, 269-278.

${ }^{18}$ CONGREGAZIONE PER LA DOTTRINA DELLA FEDE, Lettera “Communions Notio” su alcuni aspetti dela Chiesa intesa come comunione (28/05/1992) - CN 9: EV 13/1787.
} 


\begin{abstract}
Porque a Igreja que se manifesta em Pentecostes, não obstante sua irrepetível singularidade, é simplesmente a Igreja de Cristo, aquela que no Símbolo professamos com suas quatro propriedades e que por isto permanece sempre como matriz da Igreja Universal - entendida como Communio Ecclesiarum - e das igrejas particulares, assim como essas acontecem no tempus Ecclesiae.[...] É neste sentido que se pode compreender a prioridade temporal e cronológica, afirmada na Carta, da Igreja universal em relação a cada uma das Igrejas particulares e que portanto não se põe em contradição, mas antes ilumina a mútua interioridade entre a Igreja universal e a Igreja particular. ${ }^{19}$
\end{abstract}

Entre a Igreja Universal e a Igreja Particular existe uma correlação de força da mesma matriz que é a Igreja de Pentecostes com a sua irrepetibilidade: Por isto a dimensão mistérica precede ontologicamente e temporalmente as Igrejas particulares. ${ }^{20}$ A Congregação afirma que com precedência "ontológica" se entende a Igreja como mistério, tal como os Padres a interpretavam desde a criação; ao invés, com precedência "temporal" se vê a manifestação em Pentecostes da Igreja na diversidade de línguas, com um olhar missionário, portado daquela universalidade que seria participada às Igrejas que dali a pouco seriam fundadas pelos Apóstolos. ${ }^{21}$ Para afirmar a prioridade da Igreja universal sobre a particular se citam na Nota duas referências patrísticas tiradas da segunda Carta aos Coríntios de São Clemente Romano e do Pastor de Hermas. $^{22}$

A importância desta noção é dada pelas consequências eclesiológicas que derivam sobre o papel do bispo de Roma e do colégio Episcopal no interior da vida da Igreja. Um dos comentários oficiais à Communionis Notio assinado por A. Sicari ${ }^{23}$ releva que a intenção dos padres conciliares era de superar o impasse "universalístico" que levara a coincidir a Igreja universal com a Igreja de Roma fazendo das Igrejas particulares suas "filiais".

\footnotetext{
${ }^{19} \mathrm{CDF}$, La Chiesa come comunione, 84-85.

${ }^{20}$ CF. RATZINGER, J. “L'ecclesiologia della “Lumen Gentium”. In OR 04/03/2000, p. 6.

${ }^{21}$ CF. CATTANEO, A. La Chiesa locale, fondamenti ecclesiologici e la sua missione nella teologia postconciliare. LEV (Libreria Editrice Vaticana), 2002, p. 132-135.

${ }^{22}$ Cf. CLEMENTE ROMANO, 2 Lettera ai Corinzi, 14,2: PG 1,345-346: "A Igreja não é de agora, mas do princípio" (o texto faz referência à Igreja espiritual como corpo de Cristo). PASTORE D'ERMA, Seconda Visione, 4: PG 2,897-900: "Creata per prima tra tutte le cose".

${ }^{23}$ SICARI, A. M. Chiesa Universale e chiese particolari, in CDF, Lettera "Communions Notio" su alcuni aspetti dela Chiesa intesa come comunione (28/05/1992). Texto e commenti, Vaticano, 1994, 61-66.
} 


\begin{abstract}
Porém ainda mais se queria promover uma sensibilidade comunal, ecumênica e missionária, dar de novo às Igrejas particulares plena consciências que nelas "está verdadeiramente presente e age a Igreja de Cristo, una, santa, Católica e apostólica” (CD 11); coligá-las entre si com a Igreja de Roma por força de sua mesma natureza; indicar na eucaristia e na união colegial dos bispos (“cum Petro et sub Petro") a raiz inextirpável e fecunda de tal comunhão. ${ }^{24}$
\end{abstract}

Esta visão teológica conciliar, segundo Sicari, foi mal compreendida e adulterada, por parte de certa teologia; daí, a necessidade de reequilibrar novamente o sistema com a expressão usada pela CDF: "a Igreja na e a partir das Igrejas é inseparável desta outra: as Igrejas na e a partir da Igreja". ${ }^{25}$ Tais teses revelam a necessidade de não ver a Igreja como associação de Igrejas particulares, portanto, como fenômeno meramente social e associativo, mas de repartir o mistério profundo da comunhão nas suas múltiplas facetas, de entender toda a Igreja particular como realidade em comunhão com toda a igreja pela verdadeira fé, verdadeira eucaristia e autêntico ministério apostólico (Cf. LG 13-14). Trata-se em síntese de não ver em chave nominalista a comunhão eclesial.

Como revelou C. Ruddy, conhecido americano, Ratzinger e CN conceberam a realidade da Igreja de Pentecostes como paradigma da relação entre Igreja universal e a Igreja particular, conjugando unidade e multiplicidade na sua mútua interioridade a ponto de deduzir que a Igreja universal tenha prioridade ontológica sobre a Igreja particular. ${ }^{26} \mathrm{~A}$ CDF e o seu prefeito visavam a opor a certas tendências teológicas e pastorais, relevando como a universalidade que esta inserida na revelação da Igreja de Pentecostes. ${ }^{27}$

Tudo isto leva à velha questão da suprema potestas na Igreja. Porque uma visão de tipo "universalístico" opta por um papel proeminente do Papa, uma visão tipo "local", opta por maior descentralização. Uma resposta "católica" às solicitações da Ut unum sint de 1995, com a qual João Paulo II pedia repensar o exercício do ministério petrino, é oferecida à Congregação da

\footnotetext{
${ }^{24}$ Ibidem, 62.

${ }^{25}$ CN 9: EV 13/1789.

${ }^{26}$ Cf. RUDDY, C. The Local Church: Tillard and the future of Catholic Ecclesiology, New York, 2006, p. 101-102.

${ }^{27}$ Cf. Ibidem, com referências a vários textos de Bento XVI e da CN.. TILLARD, J.M.R. La catholicité de I'Église locale, in RCatT 18(1993),205-215. Idem, Église catholique ou église universelle?, CrSt 16 (1995),341-359.
} 
Doutrina da Fé em um texto publicado em 1988 depois de um simpósio sobre este tema em 1996; o texto se apresenta como uma "Carta/considerações" e o título é "O primado do sucessor de Pedro no mistério da Igreja". Sobre o relacionamento Primado-Episcopado, o texto afirma que não se pode prescindir de duas premissas: a unidade do episcopado e o caráter episcopal do primado mesmo (n. 8), tendo presente quanto já afirmado pelo concilio, por exemplo em LG 27, quanto se atribui não só ao Papa, mas a todo bispo a expressão "vigários e legados de Cristo". Os dois poderes não se contrapõem, mas se compenetram um ao outro. De fato o texto da Congregação afirma no n.6:

No caso do bispo de Roma - vigário de Cristo no modo próprio de Pedro como chefe do colégio dos bispos - a sollicitudo omnium ecclesiarum adquire força particular porque acompanhada pela plena e suprema potestade na Igreja, uma potestade verdadeiramente episcopal, não só suprema, plena, universal e ordinária, mas também imediata sobre todos sejam pastores sejam fieis. O ministério do sucessor de Pedro, portanto, não é um serviço que reúne toda Igreja de fora, mas está inscrito no coração de toda Igreja particular, na qual "está verdadeiramente presente e age a Igreja de Cristo", e por isso traz em si abertura à unidade. ${ }^{28}$

Tudo isto revela aquela mútua interioridade entre a Igreja universal e a particular.

\section{O fundamento eucarístico da Igreja}

Entre Igreja universal e particular "vigora um relacionamento único e irrepetível, fundado sobre a natureza da Igreja e sobre a sua diversidade por uma sociedade natural territorial, partindo da qual é compreensível e justificado o relacionamento que intercorre entre o Papa e o bispo". ${ }^{29}$ A natureza sacramental e eucarística da Igreja é de grande utilidade para compreender o relacionamento entre universal e particular: de fato a eucaristia além de tornar presente o mistério da Igreja, como celebração cultual e, de resto, como qualquer ato sacramental, tem também a característica de estar situada em um determinado tempo e espaço. A eucaristia pode ser celebrada só por uma

${ }^{28} \mathrm{CDF}$, Il primato del sucessore di Pietro nel mistero dela Chiesa, LEV, Città del Vaticano 2002,14 .

${ }^{29}$ RAHNER, K. Episcopato e primato in RAHNER, K. - RATZINGER, J. Episcopato e primato, 26. 
determinada comunidade em um lugar preciso. Disto deriva uma consequência importante: sem comprometer o caráter de universalidade própria da Igreja, esta, todavia, por força da sua mesma essência intima, tende a uma concretização e atualização local. Portanto, a eucaristia evento local não só acontece na Igreja, mas torna presente a Igreja inteira. Não só existe a eucaristia porque existe a igreja, mas existe a Igreja porque existe a eucaristia.

\begin{abstract}
A Igreja existe e se conserva também como totalidade, só porque atua e completa com constante reiteração o único e compreensivo evento dela, isto é, a eucaristia. Mas porque este evento é essencialmente de natureza local, em um ponto do espaço e do tempo, em uma comunidade local, por isso a Igreja local não é só uma agência da Igreja universal una fundada em certo modo em segundo tempo, e que poderia ser muito bem omitida, mas é o evento desta mesma Igreja universal. ${ }^{30}$
\end{abstract}

Em definitivo, a Igreja particular surge não por fragmentação diminuída do cosmo da Igreja inteira, mas pela concentração da Igreja, traduzida em acontecimento. Tudo isso é de grande importância para compreender significado e articulação do relacionamento entre primado e episcopado: na medida em que a Igreja é universal e deve ser una também na sua constituição historicamente perceptível, na mesma proporção existe o primado. Na medida em que a mesma Igreja uma e universal se manifesta na localidade e precisamente deste modo atinge sua máxima atuação. Isso é na celebração eucarística, na mesma proporção existe o episcopado de direito divino.

A máxima manifestação de eclesialidade se dá na Igreja particular como comunidade reunida pelo Espirito Santo, mediante ao Evangelho e a eucaristia, confiada ao cuidado pastoral do bispo. O ministério apostólico se coloca entre a presença e ação do ressuscitado na Igreja e sua acolhida da parte da comunidade, "no ponto de intersecção daquela corrente vital que vai do Cristo morto e ressuscitado que dá seu Espirito e a Igreja inteira que, surgida dos mistérios pascais, ama seu esposo. Como dizer que a teologia do ministério ordenado está entre a cristologia e eclesiologia". ${ }^{31}$ Justamente por sua natureza, a eucaristia mantém em pé a dialética localidade - universalidade: essa, enquanto momento celebrativo reclama pela localidade, enquanto comunhão com Cristo reclama pela universalidade. Conservar a Igreja na comunhão com Cristo e,

\footnotetext{
${ }^{30}$ Ibidem, 32.

${ }^{31}$ SEMERARO, M.. Il prete: uomo in servizio, Trani: Vivere In, 1982, p.16.
} 
portanto, na unidade e objetivo da única episkopé da qual participam os bispos e o Papa como bispo de Roma. Todo bispo individual conserva tal unidade ad intra através da colaboração e corresponsabilidade com os sacerdotes, religiosos e leigos e ad extra através da plena comunhão com os outros bispos e com o bispo de Roma. Toda Igreja particular reconhece nas outras igrejas particulares a verdadeira Igreja de Deus em um lugar do qual a expressão máxima é a concelebração eucarística. Ao mesmo modo cada bispo reconhece nos outros bispos a mesma graça ministerial e responsabilidade de serviço de estar também com eles em comunhão de fé, de amor e de intenções para o bem da Igreja de Deus. Neste quadro eclisiológico se insere o ministério de comunhão querido por Cristo, sustentado pelo Espirito Santo e confiado a uma Igreja particular e confiado a um bispo de um modo todo especial: A sollicitudo omnium ecclesiarum e a koinonia eclesial que competem a todo bispo, estão expressas de modo particular como bispo de Roma. A Igreja particular de Roma inscreve toda Igreja particular na comunhão de fé e de testemunho dos apóstolos Pedro e Paulo enquanto centrum unitatis, fazendo com que a comunhão seja efetiva e não presumida, garantida e não negociada. Garantir a unitas fidei catholicae não significa que é Pedro a criar a unidade: essa provém do Espírito do Senhor e é oferecida em toda eucaristia. Contudo compete a Pedro a tarefa de manter, difundir, promover a comunhão visível dos crentes.

E como Pedro não é aquele que "partindo do qual" se edifica a Igreja de Deus, mas aquele que consente ao grupo apostólico de tornar-se, com a própria koinonia na confissão da fé, o autêntico fundamento (Ef 2,20), o bispo de Roma não é aquele "partindo do qual" se edifica a Igreja de Deus, mas aquele que consente ao ministério de seus "irmãos e co-bispos" de desembocar na comunhão de suas igrejas. A missão do bispo da sé apostólica não se coloca acima da missão episcopal enquanto tal, mas no seu seio e ao seu serviço. ${ }^{32}$

O primado da Igreja de Roma provém do singular testemunho católico de Pedro e Paulo, que eles coroaram com martírio. O martírio exprime claramente a qualidade do primado do pescador de Cafarnaum: Pedro foi constituído acima dos outros apóstolos como líder, chefe do colégio para que tudo aquilo está nele na sua fé até o martyria esteja também nos outros. O bispo de Roma tem acima o cargo de ser o guardião e a garantia da tradição apostólica

${ }^{32}$ TILLARD, J.M.R. Il vescovo di Roma, 138. 
pondo-se em continuidade com o testemunho da fé dada por Pedro. Além disso, como a confissão de fé dos apóstolos e sua episkopé são um todo único com a fé de Pedro, que é o vínculo da comunhão, do mesmo modo os bispos não são vigários do Papa, mas encontram nele o centrum unitatis. A Igreja de Roma tem a tarefa de tornar visível o primado de Pedro no seio do colégio apostólico como serviço à busca do bem comum, na vigilância, no sustento, no testemunho da fé apostólica, na unidade mesmo na diversidade de tradições.

À luz desta leitura, cai a visão do Papa como super-bispo que se impõe como principio do colégio, garantia, fonte causa mesma da legitimidade do ministério episcopal e da plena comunhão com todo o corpo eclesial. O bispo de Roma tem uma função específica no seio da Igreja, mas seu primado não pode anular a colegialidade ou fazê-la seu instrumento de poder. No coração do corpo episcopal se põe o ministério primacial, cuja potestas está em função da potestas dos irmãos bispos, em continuidade com o confirma fratres tuos. Por isto, o bispo de Roma tem sobre a Igreja um "pleno, supremo e universal poder que pode sempre exercer livremente". ${ }^{33}$ Ser a suprema e última instância não que dizer que o bispo de Roma interfira continuamente na administração das outras dioceses, mas que intervém para proteger sejam os bispos sejam seus diocesanos: a potestade de cada bispo resulta assim afirmada, fortificada, reivindicada.

Esta visão do primado petrino não diminui quanto a tal propósito afirmara o Vaticano I, mas ao contrário o integra apresentando-o em uma ótica que não seja meramente jurídica. O bispo de Roma tem o encargo de velar seus irmãos para estarem em comunhão de fé e de amor como sigilo da catolicidade e da unidade da Igreja. Os Padres do Vaticano I não utilizaram a mesma linguagem; também no conteúdo pretendiam a mesma coisa: e eles falavam de "jurisdição", termo que ao longo dos séculos assumiu significados diferentes. A expressão primatus iurisdictionis é aplicada tanto a Pedro, quanto aos seus sucessores, divergindo de uma visão "honorífica" do poder do Papa a favor de uma configuração jurídica desta potestas verdadeira e própria. ${ }^{34}$ Trata-se na realidade de um poder de "apascentar", "reger" e "governar" toda a igreja que exige ipso facto a subordinação hierárquica e a obediência, não só questões de fé e de moral, mas também em matéria de disciplina e governo da própria Igreja.

É então, juridicamente falando, um direito e poder de reger a Igreja naquilo que concerne à fé e naquilo que diz respeito à disciplina. O que implica também o

\footnotetext{
${ }^{33}$ LG 22: EV 1/337.

${ }^{34}$ Cf. DH 3060-3065.
} 
direito e o poder de fazer-se obedecer. Nestas afirmações existe uma verdade que não pode ser nunca posta em discussão, porque é a verdade de fé da nossa Igreja expressa por um Concílio, ainda que seja verdadeiro que estas expressões são interpretadas e traduzidas com uma "linguagem" corrente. Também a formula ex sese, non ex consenso Ecclesiae, utilizada para indicar o juízo infalível do Papa há de ser interpretada corretamente. A infalibilidade é aquele carisma particular pelo qual o Papa, graças à assistência do Espirito, se faz intérprete da fé da comunidade eclesial e define com um juízo irreformável aquilo que verdadeiramente é patrimônio da fé comum dos bispos e dos fiéis. Isto não quer dizer que o Papa formule de modo arbitrário uma verdade de fé, como se as definições dogmáticas pontifícias não devessem interpretar o testemunho de fé de toda a Igreja. Portanto se exclui o recurso ao "consenso" eclesial como conditio sine qua non da validade das definições pontifícias, mas não como práxis normal, da parte do Papa, antes de proceder à proclamação de um dogma de fé.

O Vaticano II integrou e completou a visão do precedente Concílio, talvez em parte enrijecido por categorias muito jurídicas, articulando o discurso do primado no quadro do ministério episcopal. Mas isto foi só no inicio de uma reflexão teológica amadurecida nos decênios sucessivos e que nas imagens tradicionais de "sentinela", "vigilantes", "ponto de consciência", "memória da fé apostólica", emprestadas da Igreja antiga, reenviou à melhor via para recuperar o sentido autêntico do ministério confiado ao bispo de Roma. O Papa deve encarnar o cargo confiado pelo o Senhor a Pedro de confirmar os irmãos na fé mediante as solicitações que partem antes do coração do que de atos jurídicos, que são expressão primeiramente de solidariedade humana e cristã. Esta solicitude do bispo de Roma o leva a ser um primus servus servorum Dei. No colégio apostólico o bispo de Roma tem a função particular de manifestar que todos os seus irmãos bispos são servidores: a bondade de Deus. Porque ele é o primeiro, ao qual se pensa logo se busca o pensamento e a atitude da Igreja, cabe a ele mostrar ao mundo que ela é sacramento da misericórdia de Deus.

\section{O primado na sinodalidade}

A reflexão da autêntica natureza do bispo de Roma nos permite de colher como a estrutura da Igreja não pode ser modelada em base às formas de governo do tipo autocrático ou despótico das monarquias absolutas ou constitucionais nem, de outra parte, sobre pauta do modelo democrático. A Igreja desde sempre procurou garantir dois elementos fundamentais para ser a verdadeira Igreja de 
Deus: apostolicidade e unidade. Para conseguir este intento, as comunidades eclesiais tiveram necessidade de uma hierarquia não de tipo oligárquico nem parlamentar, mas sinodal. O dinamismo sinodal implica um envolvimento de todos os membros e não só da hierarquia a fim de crescer na fé e na caridade. No interior desta base eclesiológica, o poder do bispo de Roma tem o escopo de favorecer a comunhão das Igrejas na caridade. O mesmo Concílio ou a vida sinodal das Igrejas de uma região eclesiástica exigem um ministério de comunhão: o Papa, isto é, deve primeiramente "receber" e a seguir "aprovar" quanto as Igrejas particulares e os organismos de comunhão ao nível regional ou sinodal decidem, se bem que a "recepção" deve acontecer de modo "crítico".

A primeira via para orientar o exercício do papado para uma maior sinodalidade, depois do Vaticano II, foi a instituição do sínodo dos bispos com motu proprio de Paulo VI Apostolica Sollicitudo de 1965. A redescoberta ou maior valorização da dinâmica sinodal no interior da Igreja exprime claramente o deslocamento de uma lógica centrípeta ao espirito de serviço na corresponsabilidade de todos os membros, e a recuperação da bipolaridade eclesial entre o colégio dos bispos e primado romano. O dinamismo sinodal deve respeitar aquele da sinaxis eucarística, não o esquema monárquico ou democrático, que não se adequam à natureza da Igreja. Portanto na sinodalidade das Igrejas, a "presidência" correspondente a um primus não tem um valor nominal ou representativo; porque o Papa é uma autoridade, detém concretamente um poder, mesmo na comum e igual responsabilidade e dignidade episcopal que ele compartilha com os outros bispos. Além de tal primado se nutre da escuta da fé comum dos fiéis e se prodigaliza na ajuda recíproca em tomar decisões comuns sem nenhuma presunção ou ímpeto de comando, mas com o único desejo de alcançar o bem da Igreja.

Semelhante exercício do ministério primacial responde à lógica da subsidiariedade, um termo que teve particular "sucesso" sobre tudo nos anos antes e depois do Concílio. Subsidiariedade, aplicada ao primado petrino, significa serviço a autêntica catolicidade das Igrejas, recurso à sede apostólica em função da ajuda e não da suplência, serviço desenvolvido na comunhão fraterna e para a tutela da fé comum, mesmo respeitando as tradições e as leis próprias de cada Igreja. ${ }^{35}$ Tudo isto implica um audacioso aprofundamento do

\footnotetext{
${ }^{35}$ O uso do termo "subsidiariedade" foi posto em discussão pelo sínodo dos bispos e pela posterior exortação apostólica "Pastores Gregis" n. 56, na qual se opta por uma maior clareza e caráter teológico do termo "comunhão". Um estudo aprofundado sobre o tema é: F. NIGRO, Il vescovo di Roma, 262-266.
} 
ministério do Papa de modo a garantir, em certo sentido até "restituir" determinados poderes que as conferências episcopais ou os bispos e os patriarcas poderiam ou, talvez, deveriam também exercer livremente sem uma intervenção direta e imediata de Roma. Indubitavelmente, deste ponto de vista a Igreja completou notáveis passos nos últimos decênios, e, se for verdade que a estrada a percorrer é ainda longa, contudo o atual pontificado de Francisco deixa entrever mudanças significativas no plano da sinodalidade:

Dado que sou chamado a viver aquilo que peço aos outros, devo pensar também numa conversão do papado. Compete-me, como Bispo de Roma, permanecer aberto às sugestões tendentes a um exercício do meu ministério que o torne mais fiel ao significado que Jesus Cristo pretendeu dar-lhe e às necessidades atuais da evangelização. O Papa João Paulo II pediu que o ajudassem a encontrar "uma forma de exercício do primado que, sem renunciar de modo algum ao que é essencial da sua missão, se abra a uma situação nova". Pouco temos avançado nesse sentido. Também o papado e as estruturas centrais da Igreja universal precisam de ouvir este apelo a uma conversão pastoral. O Concílio do Vaticano II afirmou que, à semelhança das antigas Igrejas patriarcais, as Conferências episcopais podem "aportar uma contribuição múltipla e fecunda, para que o sentimento colegial leve a aplicações concretas". Mas este desejo não se realizou plenamente, porque ainda não não foi suficientemente explicitado um estatuto das Conferências episcopais que as considere como sujeitos de atribuições concretas, incluindo alguma autêntica autoridade doutrinal. Uma centralização excessiva, em vez de ajudar, complica a vida da Igreja e a sua dinâmica missionária. ${ }^{36}$

A relação Papa-bispo declina-se em uma série de relacionamentos ad intra e ad extra do mundo católico, sejam nas relações com Roma e Igrejas locais, seja na visão ecumênica, como o Papa João Paulo II teve em vista na Ut unum sint de 1995. ${ }^{37}$

Primeiramente emerge o papel das Conferências episcopais no interior do mundo católico. Partindo do princípio que João XXIII nucleou no inicio do seu mandado in necessariis unitas, in dubbis libertas, in omnibus caritas, ${ }^{38}$ possamos afirmar que o critério deve animar é a caridade nas relações inter-

\footnotetext{
${ }^{36}$ FRANCISCO, PP. Exortação Apostólica Evangelii Gaudium, 32.

${ }^{37}$ Digno de nota é o estudo de NIGRO, F. Il vescovo di Roma, p. 213-332.

${ }^{38}$ JOÃO XXIII, Ad Petri cathedram, 29/06/1959: AAS 55(1959), p. 513.
} 
pessoais e institucionais Papa-bispos, Roma-Igrejas locais. Hoje se reflete sobre o autêntico estatuto teológico das Conferências episcopais. As afirmações do Papa Francisco impulsionam para uma maior responsabilidade porque as suas decisões se apoiam e são realmente e não só formaliter expressões "no colégio" e "do colégio"; portanto, em virtude daquela localização que diz respeito ulterior ao princípio da encarnação do Evangelho e da Igreja, as decisões tomadas podem assumir um valor sempre mais determinante na vida daquelas regiões ou nações, tanto que não por força, se não injetam matéria grave ou delicadíssima deveriam ter e/ou requerer o placet de Roma. Isto não por aversão em confronto a Roma, absolutamente antes o afeto e a estima pelo Papa aumentam sempre mais, mas por aquela sadia e necessária corresponsabilidade que toda Igreja vive no seu território enquanto guiada por autênticos pastores e sucessores dos apóstolos. Nisto se coloca também o papel da Cúria Romana e da sua mediação e auxílio ao romano pontífice no exercício do seu ministério. Não por acaso o mesmo Papa Francisco deseja reconfigurar com um corte diverso, talvez ainda mais pastoral, e, mais adaptado às situações concretas das várias regiões e/ou nações.

Uma ulterior forma de colegialidade que nos últimos anos teve início, cujo mérito especial se deve antes a Paulo VI e depois a Bento XVI, foi o sínodo dos bispos. Papa Ratzinger os presidiu diversos, mas estes foram também um modus para exprimir a colegialidade, certamente imperfeita porque não participa todo o episcopado, mas mesmo assim sempre é sinal daquela comunhão que na Igreja os bispos vivem e que leva operativamente a uma colaboração.

\section{Para concluir}

Retomo o pensamento de um conhecido teólogo ortodoxo O. Clément para tecer as conclusões.

Em verdade, a verdadeira S. Pedro é críptica, e se compreende bem ainda como para os cristãos dos primeiros séculos a Igreja de Roma fosse venerada como a Igreja dos apóstolos e mártires Pedro e Paulo, e em seguida dos bispos mártires, e como sua função mais verdadeira não podia que ser - e permanece ainda hoje verdadeira a intuição de Atenágoras I aquela de martyria, no duplo e único sentido de testemunha e de martírio. ${ }^{39}$

${ }^{39}$ CLÉMENT, O. Roma diversamente Um Ortodosso di fronte al papato. Milano, 1998, p. 88. 
O mesmo teólogo ortodoxo traz à mente o "martírio" do Pai onipotente no sentido do mistério trinitário: "em Deus, o princípio da unidade é a Pessoa do Pai, que é o mistério de uma paternidade sacrifical e libertadora" ${ }^{40} \mathrm{O}$ primado petrino é posto assim no sentido do mistério trinitário da "paternidade sacrifical e libertadora do Pai", doando a este serviço eclesial uma conotação de comunhão e de martírio conjuntamente. O Pai se sacrifica para libertar, compadecendo no Filho, morrendo com o Filho. Mesmo usando analogicamente tal afirmação, penso que a síntese de toda esta pesquisa nos aproxima do Can. 34 dos apóstolos, onde entre prôtos e colégio, como entre cabeça e corpo, e como ainda Pai e Filho no Espírito, não existe nunca desunião ou falta de harmonia, mas amor que se doa. ${ }^{41} \mathrm{~A}$ ideia capital oferecida pela mais profunda e alta teologia ortodoxa é de dar ao ministério do bispo de Roma a densidade "mistérica" que mais the compete do que as fatias somente "jurídicas" ligadas a poderes, direitos e comando ${ }^{42}$ Com efeito, o ministério autenticamente episcopal do Papa revela esta densidade mistérica e eucarística, de tipo sacrifical memorial e comunal que bem exprime o seu sentido em relação aos bispos. Estas três dimensões da realidade do episcopado bem condizem ao papado. Antes de tudo o bispo de Roma é memória "pascal" da Misericórdia e do amor infinito de Deus por todo o homem e criatura - como o Papa Francisco está reforçando, e reenviando àquele mistério de paixão - morte e ressurreição, centro vivo da nossa fé cristã. Além disso, se empenha por um ministério "sacrifical", de "ofertório de si" para o bem de todos os irmãos bispos e fiéis, e isto se percebe pelas suas intervenções ministeriais e caritativas ordinárias. Não por último, se revela o sentido da comunhão proposta e vivida na diaconia do Servus Servorum Dei que faz da Igreja uma única família reunida em nome da Santíssima Trindade (Cf. LG 4). Portanto, o augúrio mais verdadeiro é de poder construir, juntos, o "templo santo de Deus" com pedras vivas que não pensam na diversidade como limite, mas lhe dão um valor "artístico", obra do Espírito, e visam à unidade que exprime assim a catolicidade da Igreja.

\footnotetext{
${ }^{40}$ Ibidem.

${ }^{41}$ Costituzioni Apostoliche VIII, 47,34: SChr 336,285: "É preciso que os bispos de cada nação saibam qual deles é o primeiro (prôtos) e considerem-no cabeça (kephalè); também se for função de cada um regular as coisas da própria diocese e dos lugares que lhe fazem parte, não devem fazer nada sem seu consentimento. Ele, porém, de sua parte não deverá jamais fazer nada sem o consentimento de todos os outros; assim reinará a concórdia e Deus será glorificado por meio do seu Filho no Espírito Santo."

${ }^{42}$ Cf. RUDDY, C. The Local Church, p. 131-133.
} 


\section{Referências bibliográficas}

BATTIFOLI, P. Cathedra Petri, études d'histoire ancienne de l'Église, Unam Sanctam 4, Paris, 1938.

CATTANEO, A. La Chiesa locale, fondamenti ecclesiologici e la sua missione nella teologia postconciliare, Città del Vaticano: Libreria Editrice Vaticana (LEV), 2002.

CIPRIANO DI CARTAGINE, Lettera 59,14: CCSL III C, 361-362.

CLÉMENT, O. Roma diversamente Um Ortodosso di fronte al papato. Milano, 1998.

CLEMENTE ROMANO, 2 Lettera ai Corinzi, 14,2: PG 1,345-346.

CONCÍLIO VATICANO II, Const. dogm. “Lumen Gentium”, 1964.

CONGREGAZIONE PER LA DOTTRINA DELLA FEDE, Il primato del sucessore di Pietro nel mistero dela Chiesa, Città del Vaticano: LEV, 2002.

CONGREGAZIONE PER LA DOTTRINA DELLA FEDE, Lettera “Communions Notio" su alcuni aspetti dela Chiesa intesa come comunione (28/05/1992) - CN 9: EV 13/1787.

FRANCISCO, PP. Exortação Apostólica “Evangelii Gaudium”, 2013.

IRENEO DI LIONE, Adversus Haereses, III, 3,1-3: PG 7, 848-84.

JOÃO XXIII, Ad Petri cathedram, 29/06/1959: AAS 55(1959), p. 513.

NIGRO, F. Il vescovo di Roma, "Initium episcopatus" nell'ecclesiologia di communione di J.M.R. Tillard o.p., Assis: Cittadella Editrice, 2011.

O’COLlinS, G. Peter as Easter Witness, in “The Heytrop Journal” 22 (1981) p. 1-18.

PASTORE D'ERMA, Seconda Visione, 4: PG 2,897-900.

PHILIPS, G. La Chiesa e il suo mistero nel Concilio Vaticano II. Storia, texto e comento della Costituzione Lumen Gentium, vol. II, Milano, 1969.

PIÉ-NINOT, S. Ecclesia in et ex ecclesiis (LG 23). La catolicidad de la “Communio Ecclesiarum”. In CHICA, F. - PANIZZOLO, S. - WAGNER, H. (ed.). Ecclesia tertii millennii advenientis. Casale Monferrato (AL), 1997. 
PIO IX. Lettera apostolica Mirabilis illa constantia, 4 de marzo 1875: DH 3117.

RAHNER, K. Episcopato e primato in RAHNER, K. - RATZINGER, J. Episcopato e primato.

RATZINGER, J. “L'ecclesiologia della “Lumen Gentium”. In OR 04/03/2000, p. 6.

RATZINGER, J. Primato, Episcopato e "successio apostolica". In RAHNER, K. - RATZINGER, J.. Episcopato e primato. Brescia: Morcelliana.

RUDDY, C. The Local Church: Tillard and the future of Catholic Ecclesiology, New York, 2006.

SEMERARO, M.. Il prete: uomo in servizio, Trani: Vivere In, 1982.

SICARI, A. M. Chiesa Universale e chiese particolari, in CDF, Lettera "Communions Notio" su alcuni aspetti dela Chiesa intesa come comunion (28/05/1992). Texto e commenti, Vaticano, 1994.

TILLARD, J. M. R.. Chiesa di Chiese. L'ecclesiologia di communione. BTC 59, Brescia: Queriniana, 1989.

TILLARD, J. M. R. Église catholique ou église universelle?, CrSt 16 (1995),341-359.

TILLARD, J.M.R.. Il vescovo di Roma, BTC 47, Brescia, 1985.

TILLARD, J.M.R. La catholicité de I'Église locale, in RCatT 18(1993), 205-215.

\section{Filippo Santoro}

Doutor em Teologia pela Pontificia Università Gregoriana

Consultor do Pontifício Conselho para os Leigos

Taranto - Itália

E-mail: segreteriavescovo@taranto.chiesacatolica.it

Recebido em: $17 / 10 / 14$

Aprovado em: 20/10/14 